\title{
NO CENTRO DO IMPASSE: LER E REESCREVER MACHADO DE ASSIS COM ESTUDANTES DO ENSINO MÉDIO
}

\section{IN THE CENTER OF THE IMPASSE: READING AND REWRITING MACHADO DE ASSIS WITH HIGH SCHOOL STUDENTS}

\author{
Carla Cristiane Martins VIANNA ${ }^{1}$
}

\begin{abstract}
Resumo: Por razões várias, a leitura de autores clássicos pelos jovens tem sido questionada na atualidade. Esse artigo pretende refletir sobre o ensino de literatura no Ensino Médio com textos de Machado de Assis a partir da exposição e análise de uma atividade de leitura e escrita literária que resultou em recriações de contos machadianos, mais especificamente, de "Noite de Almirante" (1884) e "Missa do galo" (1894). Para tanto, serão apresentadosos contos machadianos trabalhados, bem como analisadas duas produções textuais dos estudantes. Tais análises serão realizadas à luz de textos teóricos dedicados à questão do letramento literário, trabalho que resulta numa exposição de motivos para que autores como Machado de Assis sejam lidos, discutidos e sirvam de inspiração para o exercício da escrita literária em sala de aula.
\end{abstract}

Palavras-chave: Leitura literária. Recriação literária. Prática de ensino. Machado de Assis. Letramento literário.

Abstract - For various reasons, reading classical authors by young people has been questioned. This paper intends to reflect upon literature teaching in High School using Machado de Assis' works. It presents and analyzes an activity of literary reading and writing that resulted in retellings of Machado's tales, more specifically, of "Noite de Almirante" (1884) ['Admiral's Night'] and "Missa do galo" (1894) ['Midnight Mass']. In order to do so, the Machadian short stories are presented, as well as students' textual productions. Such analyses are carried out in the light of theories dedicated to the issue of literary literacy, which results in an exposition of reasons for reading and discussing authors such as Machado de Assis, who serves as an inspiration for the exercise of literary writing in the classroom.

Keywords: Literary reading. Literary recreation. Teaching practice. Machado de Assis. Literary literacy.

\section{Considerações iniciais}

O presente artigo se propõe a apresentar uma análise sobre o ensino de literatura tendo como ponto de partida para o debate uma atividade de leitura e escrita (ou melhor, reescrita) literária realizada com estudantes do ensino médio de uma escola pública. Essa prática de ensino dedicada aos contos machadianos orientará a discussão aqui empreendida, a qual visa percorrer o seguinte itinerário reflexivo: a problematização de alguns impasses vivenciados pelo professor(a) de língua portuguesa e literatura e o papel da leitura e da reescrita no letramento literário.

\footnotetext{
${ }^{1}$ Docente do Instituto Federal Sul-rio-grandense (IFSul). Doutora em Literatura Brasileira pela URGS. E-mail: ccmvianna@gmail.com.
}

Revista Graphos, vol. 21, n²1, 2019 | UFPB/PPGL | ISSN 1516-1536 
Uma questão que perpassa essencialmente a discussão apresentada é a da legitimidade da leitura de autores canônicos com estudantes da educação básica com objetivo de formar leitores. Trata-se de um problema que apresenta lugar de destaque na argumentação porque, na contemporaneidade, assume um viés ideológico que orienta escolhas didáticas e, consequentemente, desenha os traços do trabalho com o texto literário na sala de aula. Assim, o intuito é pensar o letramento literário mediante a prática da leitura e da reescrita de contos machadianos no chão histórico desse começo de século XXI.

\section{As vertentes do impasse}

Existe um impasse no ensino de literatura no Brasil neste início de século XXI. Trata-se de um impasse formado por várias vertentes, potencializadas quando se pensa no ensino da rede pública, uma vez que a situação da educação literária nas escolas públicas brasileiras não pode ser dissociada da realidade material enfrentada pelos docentes que se dedicam a essa tarefa.

Ensinar literatura no ensino público brasileiro é confrontar-se cotidianamente com as condições de trabalho oferecidas pelo Estado: precariedade dos ambientes escolares, falta de recursos didáticos, professores sem carreiras docentes que considerem as atividades exigidas pela prática de ensinar, desvalorização salarial. Enfim, se já é difícil que o profissional de Letras se oriente em sala de aula no cenário da contemporaneidade, quando esse professor está pisando o chão da escola pública, as barreiras parecem ser ainda mais íngremes. Ou seja, o impasse se potencializa quando estamos tratando da educação de jovens estudantes da rede pública.

Como educar jovens para a fruição da arte literária e para o conhecimento da história social e cultural sem os meios para fazê-lo? Para que a educação literária se concretize, é necessário que as escolas possuam bibliotecas atualizadas, projetores, materiais para impressão, laboratórios de informática e, sempre é bom lembrar, professores que tenham tempo para a leitura e releitura de textos. Em tempos nos quais nem sempre o docente recebe o seu salário integralmente, parece utópico pensar num ambiente educacional que proporcione os meios para que ele exerça a sua atividade.

Qualquer tipo de generalização é um tanto perigoso, e falar em escolas públicas e precariedade de recursos pode nos levar a estabelecer aqui um cenário nebuloso, do qual não há escapatória. Convém a mediação: há escolas públicas que, de uma forma ou outra, não se enquadram nesse panorama, seja por contarem com recursos de municípios que investem em educação, seja pela habilidade de seus gestores ou pela parceria com outros setores da 
sociedade civil. Há que se considerar também que esse ainda não é o panorama das escolas pertencentes à rede federal de educação profissional, científica e tecnológica, cujas bases se encontram na lei 11.892 de 29 de dezembro de 2008.

O texto literário deve ter espaço central na aula de literatura. Eis a máxima presente em muitos dos estudos dirigidos à questão do letramento literário; no entanto, o que parece ser uma obviedade no que diz respeito à formação de leitores nem sempre é uma tarefa simples de ser cumprida. Para que o texto literário esteja no centro da aula para uma turma de trinta ou quarenta estudantes, é preciso que haja, no mínimo, um exemplar para cada dupla ou um equipamento para projetá-lo. E isso nem sempre é possível sem o esforço pessoal de professores que, não raro, investem os recursos próprios para que consigam realizar o seu trabalho.

Essa pode não ser a situação da totalidade das escolas públicas brasileiras, mas é o que encontramos em muitas delas. Foi o que encontrei quando comecei a ministrar aulas de literatura na rede estadual do Rio Grande do Sul em 2005: muitos estudantes em sala de aula, poucos volumes nas bibliotecas e quase nenhum recurso didático, como cópias e projetores. $\mathrm{Na}$ época, foi preciso que eu aprendesse a ser professora de literatura com as condições que tinha, ou melhor, apesar delas.

Resiliência educacional bem poderia ser matéria das graduações em licenciaturas do nosso país, já que constitui uma habilidade fundamental para quem está no início de sua trajetória profissional. É preciso ler e escrever a literatura brasileira com nossos alunos justamente no sentido de apropriar-se da palavra, matéria-prima da arte literária. Eis que temos aqui outra vertente do impasse com o qual se depara o professor de português ou literatura, ou de português e literatura: a literatura não é mais unanimidade no trabalho de leitura e produção textual, ao contrário.

No cenário educacional brasileiro, a literatura tem sido subtraída das salas de aulas por diferentes razões, e a situação atual do ensino de literatura demonstra que talvez tenhamos ido de um extremo ao outro ao deslocarmos a literatura de um espaço sacralizado para uma contemporaneidade na qual um texto literário tem o mesmo espaço de outros gêneros textuais. Se antes ler e discutir Machado de Assis e Guimarães Rosa, por exemplo, era o procedimento esperado de um professor de literatura do ensino médio, hoje não há consenso entre os profissionais da área sobre a adequação didática de trabalhar autores densos como eles. Nesse contexto, ensinar literatura no ensino básico é procurar, cotidianamente, afirmar o valor do texto literário para a formação integral do estudante, mas também significa uma pesquisa 
constante sobre a própria prática docente, pois não há mais certezas quando o assunto é o ensino de literatura. Rildo Cosson registra essa tendência:

\begin{abstract}
No melhor dos casos, os textos literários se perdem entre receitas culinárias, regulamentos, roteiros de viagem, fôlderes publicitários, bulas de remédio e textos jornalísticos que são esmagadora maioria. Essa nova organização do livro didático está de acordo com as teorias mais recentes do ensino de língua, as quais pressupõem que o leitor competente é formado por meio do contato com textos de uso social variado. Além disso, tendem a considerar que o texto literário, por seu caráter artístico, não apresenta a regularidade necessária para servir de modelo ou exemplo para o exercício da escrita, logo devendo ceder lugar a outros tipos de texto que apresentem tais características (COSSON, 2014, p. 13).
\end{abstract}

O texto literário é um tipo de texto apresentado entre os diversos gêneros textuais; assim, ele tem perdido espaço nas aulas de língua portuguesa, e a literatura como disciplina tem desaparecido dos currículos escolares. Ou seja, temos uma equação na qual a literatura tem sido excluída das salas de aulas por diferentes razões. Talvez isso explique Garfield e Mafalda mais presentes nas questões da prova de linguagens do ENEM e nas práticas de ensino de língua materna do que Machado de Assis e Guimarães Rosa. É o próprio Cosson quem faz um balanço dessa realidade:

O resultado de tudo isso é o estreitamento do espaço da literatura na escola e,
consequentemente, nas práticas leitoras das crianças e dos jovens. No campo do
saber literário, o efeito de tal estreitamento pode ser potencialmente ainda mais
desastroso porque a escola é a instituição responsável não apenas pela manutenção e
disseminação de obras consideradas canônicas, mas também de protocolos de leitura
que são próprios da literatura. Se a presença da literatura é apagada da escola, se o
texto literário não tem mais lugar na sala de aula, desaparecerá também o espaço da
literatura como lócus de conhecimento (COSSON, 2014, p. 15).

Com o desparecimento da literatura do currículo escolar, o texto literário perderá, cada vez mais, espaço no panorama cultural do país, fato que nega aos estudantes o direito à literatura, o qual, conforme Antonio Candido (2011), é um direito humano inalienável e deveria ser garantido numa perspectiva de um ensino voltado à humanização e à formação para a cidadania. A educação literária esbarra, contemporaneamente, no fato de que a própria leitura literária tem sido, portanto, relativizada em nome de um ensino voltado a textos de múltiplos usos sociais.

Outra face do complexo dilema que estamos tentando esboçar é constituída pelo advento da textualidade eletrônica e suas implicações na formação de leitores literários, uma vez que a própria noção de leitura e de texto literário se modificou nas últimas décadas. $\mathrm{O}$ estudante do século XXI convive harmonicamente com textos em diferentes suportes, e a revolução tecnológica acrescentou mais um componente à tarefa do professor, pois "é preciso utilizar aquilo que a norma escolar rejeita como um suporte para dar acesso à leitura na sua 
plenitude, isto é, ao encontro de textos densos e mais capazes de transformar a visão do mundo, as maneiras de sentir e de pensar" (CHARTIER, 1999, p.104).

Nesse contexto, ler literatura em diversos suportes deve ser uma prática do professor antenado com as transformações tecnológicas, de tal modo que esse trabalho didático não recaia no outro extremo: desconsiderar os autores e os suportes mais antigos. Em outras palavras, a leitura de Fernando Pessoa e Clarice Lispector no suporte livro deve ser trabalhada em sala de aula tanto quanto a leitura das postagens mais recentes no blog ou no tumbler de um autor contemporâneo.

Quando eu trabalhava na rede estadual, tinha certeza de que precisava mesmo é de recursos didáticos e de uma carreira que me permitisse planejar minhas aulas. Se tivesse recursos e tempo, pensava à época, estaria tudo certo na minha prática. Acontece que não foi bem assim. Ingressei em 2011 na rede federal de ensino, mais especificamente no Instituto Federal Sul-rio-grandense, campus Camaquã. Lá tive, pela primeira vez, recursos didáticos e uma carreira que me possibilitava pensar as minhas aulas, ler, criar atividades, trabalhar em equipe, enfim, o que deveria ser uma regra, mas se trata de um sonho em nosso país.

O impasse, no entanto, é muito mais complexo do que sonha a nossa vã filosofia. As minhas certezas relacionadas ao ensino de literatura começaram a esmorecer justamente porque coincidiu com esse meu período profissional a constatação de que ler a literatura brasileira com os estudantes não era mais tão inquestionável assim. Essa percepção surgiu mediante o estudo das provas do $E_{n e m}^{2}$, a escuta do eco de algumas comunicações em eventos científicos da área de letras dedicadas a questionar a necessidade da leitura dos clássicos na escola e o testemunho da exaltação cada vez maior da emergência da cultura audiovisual e das novas tecnologias em detrimento da cultura livresca, ultrapassada e conservadora. A minha prática tinha se tornado trabalho de professora tradicional, desatualizada, careta mesmo. Mais uma vertente para o impasse de ser professora de literatura em pleno século XXI.

Nesse cenário, mesmo tendo quase todas as condições favoráveis de trabalho, muitas vezes indaguei o meu trabalho ao solicitar a leitura de algum autor mais antigo da literatura brasileira, como José de Alencar e Machado de Assis, por exemplo. Em tempos de literatura em baixa, apresentar um autor clássico não é um ato desprovido de significados. E lidar com esse fato não foi fácil. A pesquisadora Ana Crélia Dias enuncia essa tensão:

\footnotetext{
${ }^{1}$ Pesquisa que resultou na tese de doutorado intitulada Retrato de uma disciplina ameaçada: a literatura nos documentos oficiais e no Exame Nacional do Ensino Médio (ENEM), de Gabriela Fernanda Cé Luft, defendida em 2014 na UFRGS.
}

Revista Graphos, vol. 21, n²1, 2019 | UFPB/PPGL | ISSN 1516-1536 
Portanto, a grande polêmica que se estabeleceu sobre essa tensão canônica x ou não canônico parece ter favorecido a ideia de que o cânone é herança para quem tem "linhagem" com ele. Essa discriminação de público chegou a levar o Ministério da Cultura a fomentar um projeto de "tradução" de algumas obras de Machado de Assis para alunos de escolas públicas brasileiras (DIAS, 2016, p. 215).

Ao propor a leitura de Machado de Assis e de outros autores clássicos, e não obter o resultado na aprendizagem de alguns estudantes, comecei a vacilar nas minhas concepções sobre o ensino de literatura. Será que eu não estava mesmo perdendo o trem da modernidade? Ou ainda: não estaria eu afastando os meus alunos da leitura ao sugerir que lessem Dom Casmurro? Por outro lado, havia a ponderação que me fazia persistir na tarefa, pois pensava que esses estudantes mereciam viver a experiência da leitura de autores como Machado de Assis e Clarice Lispector. Na seguinte passagem, encontra-se elaborada a crença que me fez seguir trabalhando com os clássicos na escola:

Assim, se não é honesto prometer esse paraíso ao leitor, porque ler pressupõe também experiências complexas e muitas vezes fora da zona de conforto, tampouco é produtivo rotulá-lo como indivíduo em débito, uma vez que em nada acrescenta para garantir melhor acesso à literatura (DIAS, 2016, p. 216).

O meu papel como professora seria o de ocultar autores como Machado de Assis do currículo em favor de um ensino mais dinâmico, sintonizado com as últimas tendências, ou encontrar a forma mais adequada de ler esses autores (e autoras!) com estudantes que talvez não conheceriam essa literatura fora da escola? Dia desses, uma amiga, também professora de literatura, me contou que outra colega de área a chamou de "ousada" ao ouvir sobre o seu trabalho com texto de Machado de Assis no ensino médio. O que antes era norma, agora é ousadia. Impasse pouco é bobagem. É nesse sentido que, outra vez, é necessária a leitura de Ana Crélia Dias:

O constrangimento de pertencer a um país tão desigual não pode tornar o acesso ao
cânone literário um tabu, atacado por quem defende o multiculturalismo e as
questões sociais, e defendido como aura inacessível pela elite acadêmica. O ethos da
literatura de Machado de Assis ou Guimarães Rosa compreende muito do povo. É
evidente que pensar em domínio de complexidade literária, quando muitos dos
leitores sequer conquistaram com propriedade a alfabetização pode parecer um
paradoxo. Entretanto, esse real não nos pode colocar em situação de litígio tal que o
leitor fique sempre desabonado (DIAS, 2016, p. 217).

O acesso ao cânone literário constitui uma questão que deveria ser central no debate sobre o ensino de literatura na formação dos professores de Letras, pois será uma das vertentes do impasse vivenciado pelo professor não apenas na sala de aula, mas na sala dos professores, na reunião de pais, enfim, em toda a comunidade escolar. A leitura de autores clássicos não deveria ser considerada privilégio de uma elite letrada tampouco alheia às questões sociais. Nesse ponto, convém a leitura de Antonio Candido: 
Por isso é que que nas nossas sociedades a literatura tem sido um instrumento poderoso de comunicação e educação, entrando nos currículos sendo proposto a cada um como equipamento intelectual e afetivo. Os valores que a sociedade preconiza, ou os que considera prejudiciais, estão presentes nas diversas manifestações da ficção, da poesia e da ação dramática. A literatura confirma e nega, propõe e denuncia, apoia e combate, fornecendo a possibilidade de vivermos dialeticamente os problemas (CANDIDO, 2011, p. 177).

Essa tensão entre canônico x não-canônico tem uma origem política; no entanto, parece que há uma compreensão equivocada que confere a todos os autores do cânone a pecha de representativos de uma elite cultural, e, mais grave ainda, tratam-nos como símbolos do conservadorismo. Ler Machado de Assis, Graciliano Ramos ou Erico Verissimo não deveria ser considerado um investimento para uma educação voltada à manutenção da ordem social. Ao contrário, a literatura elabora formalmente a crítica à sociedade patriarcal e oligárquica brasileira.

O que se pretende aqui não é a defesa de um tempo em que a leitura do cânone, como já mencionado, era norma e não havia espaço no currículo escolar para a leitura de outros autores representativos de diversos segmentos sociais, mas a busca de um equilíbrio no qual haja lugar para os clássicos e os textos não-canônicos. O que se questiona é a validade do deslocamento do pêndulo de um extremo a outro sem mediações nem problematizações mais consistentes. Machado de Assis não pode ser descartado como representativo do status quo sem prejuízo dos estudantes e de toda a nossa cultura mais ali adiante porque "os clássicos são aqueles livros que chegam até nós trazendo consigo as marcas das leituras que precederam a nossa e atrás de si os traços que deixaram na cultura ou nas culturas que atravessaram (ou mais simplesmente na linguagem ou nos costumes)" (CALVINO, 2007, p. 11).

\section{Atividade de leitura e reescrita de contos machadianos/ Metodologia da atividade}

Na sequência, será apresentada a atividade de leitura e reescrita de contos machadianos desenvolvida com estudantes do segundo ano do Ensino médio do curso técnico integrado em Informática do campus Camaquã do Instituto Federal Sul-rio-grandense (IFSul). Esse trabalho foi realizado com a disponibilidade de recursos didáticos, tais como material impresso, alguns livros e projetor e com uma carga horária semanal para a disciplina de literatura de três períodos, pois esse curso tinha três períodos dedicados à Língua Portuguesa e três para a Literatura na grade curricular. Ou seja, havia recursos didáticos e tempo para um trabalho mais demorado com os textos de Machado de Assis.

Esse trabalho iniciou-se com a leitura em voz alta de "Noite de almirante" (1884), em uma aula e de "Missa do galo" (1894) em outra. Essas leituras foram realizadas com o grupo 
todo acompanhando os contos com material próprio, pois foram entregues cópias para que os estudantes pudessem acompanhar a leitura, fazer as suas anotações, enfim, apropriar-se do texto literário. Cabe registrar que essas leituras eram interrompidas à medida que surgiam questões a serem comentadas, dúvidas a serem elucidadas, opiniões a serem manifestadas.

Após a leitura em voz alta, foi apresentada a antologia intitulada Reescrevendo Machado, organizada por Luiz Antônio Aguiar e publicada pela editora Record em 2008, ano do centenário de morte do autor de Dom Casmurro. Essa obra foi constituída de uma compilação de contos reescritos por vários autores da própria editora, tais como Alberto Mussa, Cíntia Moscovich, Cláudia Lage, Cristóvão Tezza, Heloísa Seixas, Letícia Wierzchowski, Marcelino Freire, Mário Sabino, Miguel Sanches Neto, Nilza Rezende, Rafael Cardoso e Tatiana Salem Levy.

Na ocasião, não lemos nenhuma recriação publicada na antologia, mas sintetizei alguns enredos dos novos contos inspirados nas obras machadianas, numa tentativa de explicitar o quanto pode ser criativa uma atividade de reescrita literária. Tratou-se de um momento de aula expositiva-dialogada sobre alguns contos machadianos e o trabalho realizado pelos autores da Record, o qual teve a intenção de despertar, sobretudo, a curiosidade dos estudantes pelos contos de Machado de Assis, mas também o desejo de se arriscarem na prática de escrita criativa.

Em seguida, foi proposto o desafio de exercitar a autoria por meio da atividade de reescrita de "Noite de almirante" ou de "Missa do galo", o que poderia ser feito individualmente ou em duplas. Para tanto, eles precisaram reler os contos, escolher qual seria trabalhado por eles e escrever o novo texto mantendo o original de Machado de Assis no seu horizonte de criação. Essa etapa do trabalho foi realizada em três períodos de 45 minutos e mais algum tempo, variável, de escrita extraclasse. Concluídos os textos, foi realizado o compartilhamento das escolhas autorais de cada narrativa com o grande grupo em outra aula dedicada a esse momento.

\section{Reescrevendo "Noite de Almirante"}

Alguns estudantes se dedicaram a reescrever "Noite de almirante", um dos mais célebres contos machadianos, publicado em 1884, período em que o autor vivia sua grande fase na narrativa tanto no romance quanto nesse gênero literário. A seguir, a análise aqui empreendida se debruçará sobre o texto composto por duas estudantes da turma em questão.

Desde o trecho inicial do conto composto pelas meninas, podemos verificar que a voz narrativa foi modificada, passando a história a ser contada em primeira pessoa, mais Revista Graphos, vol. 21, n 1, 2019 | UFPB/PPGL | ISSN 1516-1536 
especificamente, pela própria Genoveva, personagem feminina central no entrecho machadiano. Essa mudança de um narrador em terceira pessoa, onisciente, para a primeira pessoa altera significativamente tanto a forma quanto o conteúdo do texto reescrito, como podemos testemunhar na leitura desse excerto:

Em um fim de tarde, eu estava costurando as roupas de meu marido, Marco Polo Altoferro, que trabalha na barbearia, quando de repente ouço duas batidas na porta. *Toctoc*

- Genoveva! Genoveva!

Reconheço a voz que me chama, é a voz de Matilde. Eu me dirijo à portaabrindo-a:

- O que foi, Matilde? Aconteceu alguma coisa?

Matilde responde ofegante:

- Você... nem sabe quem voltou.

- Quem? Voltou de onde?

Fiquei curiosa.

- Deolindo! Deolindo Venta-Grande!

Podemos perceber ainda que as estudantes optaram por escrever o novo texto introduzindo técnicas próprias dos seus repertórios de leituras prévias, como denota a presença da onomatopeia "Toctoc", ausente na narrativa machadiana. Outra questão relevante a ser notada é que elas excluíram os fragmentos descritivos presentes na narração original desde o primeiro parágrafo do conto. No texto de Machado, a história inicia com a apresentação do marujo Deolindo Venta-Grande e o seu contexto de chegada da viagem, no das estudantes, por sua vez, a personagem-narradora já começa a reconstruir a visita do ex à sua casa. Ou seja, elas parecem trazer para o seu texto o tom de uma narrativa menos descritiva, ao gosto do século XXI. A autoria presente no conto delas muitas vezes não é exercitada no ambiente escolar, como demonstra a análise de Ciana Leahy-Dios:

Talvez aí resida o cerne dos problemas pedagógicos, uma questão comum à leitura da produção literária do alunado: permitimos que eles escrevam sobre textos, mas não seus próprios textos, e muito menos, que sejam vistos como autores (que Kress [1995] estabelece como categoria diferente de escritores: aqueles seriam capazes de uma apreciação consistente e de uma produção textual crítica); a produção escrita na escola raramente é lida como intercâmbio válido de experiências culturais ou de reflexões significativas (LEAHY-DIOS, 2000, p. 25).

Essa atividade de recriação possibilita que os estudantes assumam outro papel na sua relação com o texto literário, pois, ao assumir a tarefa de recriar uma obra, o leitor passa a exercitar concomitantemente os dois papéis: o de leitor e o do autor. Assim, de uma só vez, o professor pode trabalhar a leitura e a escrita de uma forma lúdica e desafiante, ao passo que tanto uma quanto a outra permitirão que seus alunos dialoguem com os autores - e autoras de diferentes tempos e lugares.

A reescrita das estudantes demonstra que elas conseguiram apropriar-se dos mecanismos de criação literária, pois, dentre os expedientes narrativos utilizados por elas, 
podemos perceber a alternância entre inserções autorais e transcrições de trechos do conto machadiano. Além disso, cabe destacar o fato de que elas conseguiram sustentar, do início ao fim, a narrativa em primeira pessoa, como podemos ler nesse fragmento:

\begin{abstract}
Já estava escurecendo, acendi uma vela e me sentei na soleira da porta. Acabei pedindo que ele me contasse alguma coisa das terras por onde ele havia passado. A princípio ele recusou, mas acabou contando.

Entre uma história e outra, chega Matilde. Eu a convido para sentar-se também e acabamos ouvindo mais algumas histórias. Até que em um certo momento, após terminar uma das suas histórias, ele se levanta para ir embora. Mas interrompo e não o deixo ir até que Matilde veja os brincos.
\end{abstract}

As estudantes deram voz à Genoveva ao transpor o foco narrativo do conto. Não podemos deixar de comentar que, ao preponderar o ponto de vista feminino, Deolindo parece perder a centralidade da história, ao mesmo tempo em que ela surge mais assertiva que a outra Genoveva. Há, portanto, no trabalho das estudantes, uma virada em direção ao protagonismo de Genoveva tanto na forma quanto no conteúdo do conto. Nada mais ao gosto das meninas do século XXI. A reescrita literária pode ser, então, uma maneira de ressignificar a leitura escolar:

É por meio dessa atividade constante de relacionar-se (com o mundo, consigo mesmo, com outras obras) que a leitura tem sentido. Assim, é de se perguntar sobre a compartimentação de que ela é objeto dentro da esfera escolar. Salvo as relações de intertextualidade, a leitura escolar, em seu formato canônico, não autoriza ligações com aquilo que se situa fora do literário: o universo do leitor. Essa exclusão paradoxal explica a aspereza e o formalismo do exercício e o fato de que inúmeros alunos dele se afastam (Rouxel, 2013, p. 159).

A literatura só passará a ser importante para os estudantes quando eles puderem fruir o texto literário, associando-o a uma arte que permite a compreensão do mundo em toda a sua complexidade. De acordo com Rouxel, o exercício meramente formal realizado na escola mais afasta do que aproxima o aluno do hábito da leitura. Nesse sentido, o problema não é ler Machado de Assis com estudantes do ensino médio, mas talvez ler Machado de Assis com estudantes dessa etapa sem condições para tal tarefa (tempo, recursos), ou ainda com objetivos pragmáticos, que destoam do processo de formação do leitor literário.

Machado de Assis deve significar algo além do representante máximo do Realismo brasileiro para os nossos estudantes. Ainda mais porque esse fato nem é consenso na crítica literária. Ele, como os demais autores, deve ser lido visando à interação dos sujeitos com a sua obra, para que assim possam sentir a literatura em sua inteireza. Leiamos o trecho final da reescrita das estudantes:

Deolindo seguiu praia a fora, cabisbaixo e lento. Eu entrei alegre e barulhenta para contar à Matilde o que conversamos. Ela declarou achá-lo grandemente simpático.

- Muito bom rapaz. Sabe o que ele me disse agora? - disse a ela.

- Que foi?

- Que vai matar-se.

Revista Graphos, vol. 21, n²1, 2019 | UFPB/PPGL | ISSN 1516-1536 
- Jesus!

- Não se mata, não. Deolindo é assim mesmo; diz as coisas, mas não faz. Você verá que não se mata. Coitado, são ciúmes. Mas os brincos são muito engraçados.

- Eu aqui ainda não vi destes.

- Nem eu - disse examinando-os à luz. E, enfim, os guardei.

Temos aqui um outro final para "Noite de almirante", o qual termina, nessa versão, com uma conversa entre Genoveva e sua amiga, aqui chamada Matilde. Enquanto o texto original se encerrava com o narrador em terceira pessoa contando o encontro de Deolindo VentaGrande com os seus colegas marujos, na versão das meninas, não há mistério, não há filosofia do narrador: há um basta de Genoveva que parece encerrar o caso ao guardar os brincos.

\section{Reescrevendo "Missa do Galo"}

Nem todos os estudantes da turma escolheram "Noite de almirante" como inspiração para os seus textos; alguns se dedicaram a reescrever "Missa do galo", outro dos mais célebres contos machadianos, publicado em 1894, mais um exemplar da grande fase machadiana na narrativa. Nessa seção, será discutida a recriação desse conto escrita por outro estudante.

Em seu texto, esse aluno mantém o mesmo narrador do conto machadiano, ainda que introduza outro tom na narrativa, modificando, portanto, um pouco a sua composição. $\mathrm{O}$ narrador é o mesmo, mas diferente, como não poderia deixar de ser em um trabalho de recriação literária. Vejamos esse fragmento do texto reescrito:

Ia muitas vezes ao teatro, sem nunca permitir que eu fosse junto. Só algum tempo
depois me ocorreu de descobrir que, apesar de ser realmente culto, Meneses usava o
teatro como eufemismo para sua quase hipérbole de manter amores com uma
senhora, a qual havia se separado do marido. Peça teatral verdadeira era na casa,
toda vez que eu pedia para acompanhar-lhe ao teatro. A sogra fazia careta, as
escravas entravam em cena como indesejadas coadjuvantes, rindo-se. Meneses,
talvez vilão, saía e só tornava na manhã seguinte. Conceição padecera em amores ao
saber dos amores alheios de Meneses para com a senhora separada; mas, então,
calou-se, deixou sair do palco a revolta e passou a considerar muito direito o que o
marido fazia. E eu era a plateia - a elite no assento principal.

A leitura desse trecho escrito pelo estudante já nos permite verificar que ele se apropriou da narrativa machadiana, tecendo um conto no qual ele, por vezes, parece ter desenvolvido aspectos sugeridos pelo narrador original. Como nessa passagem em que o narrador avalia o comportamento dos demais moradores da casa, mesclando dados do conto machadiano, mas também interferindo na criação das personagens. Eis o que explica a seguinte afirmação: "E eu era a plateia - a elite no assento principal”. No texto inspirador, a personagem não realiza essa análise, ou autoanálise, a qual alude à identificação entre a elite e 
a plateia teatral, aproveitando a deixa do conto machadiano no qual o teatro aparece como pretexto para as saídas noturnas de Meneses. Leiamos outro trecho da reescrita do estudante:

\begin{abstract}
Não sei ao certo por quê, mas pela primeira vez me caiu na mente pensar no duplo sentido que "romances" poderia ter. Assim como uma mosca varejeira, essa divagação postou larvas na projeção da índole que eu tinha de Conceição e voou, embora eu pudesse ouvir seus zumbidos a uma certa distância. Romances ou romances? A pretexto de não deixar o ar tão sóbrio, ainda mais com a miúda luz do candeeiro, resolvi forjar um comentário espontâneo sobre as horas; mal eu fizera um gesto inclinando a cabeça para o relógio, Conceição tornou a falar-me novamente:

- Já leu a Moreninha?
\end{abstract}

Nessa passagem, fica clara não apenas a apropriação do estudante de expedientes da escrita literária como a interlocução com o texto machadiano, uma vez que ele pôs no papel as suas especulações de leitor. É admirável a percepção da ambiguidade expressa pela pergunta "Gosta de romances" feita pelo narrador a Conceição. Há nessa reescrita ainda uma relativa modernização da linguagem na qual podemos depreender o traço autoral do aluno, vislumbrado também em outros pontos do seu conto:

Em um sono magnético, no qual Conceição me colocava, concordei, queria e não queria acabar a conversação. Na rua, tudo era silêncio. O resto era silêncio. Queria fixar o olhar nela, me vidrar, mas por respeito, pela ideia imaculada, arredava, com esforço, os olhos pesados em êxtase. Tudo ficara escuro, silencioso.

A leitura da produção desse estudante nos leva a concluir que ele tem uma certa afinidade com a literatura, pois domina a tarefa de construir uma narrativa e, além disso, estabelece relações com outros textos, como a referência ao livro de Erico Verissimo presente na frase "O resto era silêncio". O exercício da leitura e da autoria literária pode também ser testemunhado nas modificações do enredo do conto, como podemos ler no fragmento a seguir:

\footnotetext{
Com a mente confusa e repleta de riscos esguios, tangentes uns aos outros, fui ao banheiro, cada vez suava mais. Pensava em Conceição, a montava na mente, minha mão montava movimentos oscilatórios suaves, depois frenéticos para cima e para baixo, alisando. Seria eu o depravado? Após alguns minutos, saí, me arrumei rapidamente e ouvi uma pancada na janela, do lado de fora, e uma voz que bradava: "Missa do galo! Missa do galo!"
}

Diversas vezes, nesses mais de dez anos em que ministro aulas de literatura, li esse conto de Machado de Assis com adolescentes e, diversas vezes, eles terminaram a leitura frustrados, um tanto indignados com essa história em que "nada acontece". A ausência de cenas nas quais o envolvimento do narrador com Conceição se concretiza tem como efeito uma recusa inicial dos jovens leitores a esse texto. Em seu trabalho, entretanto, o estudanteautor nega o erotismo irrealizado, a excitação insatisfeita, com essa cena na qual o 
personagem-narrador se masturba. Impossível pensar em algo mais em sintonia com as experiências e expectativas juvenis. Violaine Houdart-Mérot analisou a prática da reescrita literária nas aulas de literatura:

Tal é o caso da "escrita da invenção", introduzida no ensino médio desde 2001. Ela engloba "tudo aquilo que não é comentário" e "se apoia sempre nas fontes e/ou modelos". Por meio desse exercício, o texto literário poderia ser apreendido como um texto a ser reescrito, como texto "scriptível", admirável na medida em que é digno de ser reescrito, mas não sacralizado, pois nos sentimos autorizados a transformá-lo, a fazê-lo nosso, a parodiá-lo, "corrigi-lo" ou dele nos desviar. Transformar o estilo, os personagens, o contexto, o tipo de focalização de um texto é uma maneira de explorar suas virtualidades, de sondar suas possibilidades, é verdade, mas é um exercício de leitura que rompe com o princípio de fidelidade ao texto (HOUDART-MÉROT, 2013, p. 114).

Como enuncia Houdart-Mérot, o exercício da reescrita não sacraliza o texto literário, permitindo que se "explore suas virtualidades", de um modo que aproxima os estudantes da obra de um determinado autor. No entanto, a "escrita da invenção", segundo a estudiosa, teria como efeito negativo a ruptura com a fidelidade ao texto. Podemos questionar, em contrapartida, se esse preço a pagar não poderia ser justificado pelo serviço do aprimoramento da competência leitora desenvolvida em sintonia com o trabalho de autoria, o que não é pouca coisa.

\section{Considerações finais}

Por diversas razões, a literatura tem perdido terreno no currículo do ensino médio, tanto como disciplina quanto como prática de leitura e escrita, ainda mais se considerarmos os textos de autores canônicos. Nesse panorama, o trabalho em sala de aula com autores como Machado de Assis e Guimarães Rosa, por exemplo, pode ser interpretado como um posicionamento conservador e desfavorável à formação de leitores.

Essa realidade no ensino de literatura na contemporaneidade é complexa e multifacetada, podendo ser interpretada como resultado de décadas de um ensino de literatura engessado pela historicidade e pela visão pragmática, segundo a qual a arte literária seria um meio para alcançar habilidades e conhecimentos específicos. Nesse contexto, os textos literários de autores clássicos podem, ironicamente, ter assumido o ônus de práticas de ensino que lhes destinavam papéis secundários ou ainda eles podem ser considerados impróprios para o letramento literário quando a inadequação reside justamente nas condições de trabalho do professor de língua portuguesa e literatura.

Ler Machado de Assis com estudantes do ensino médio, atualmente, exige uma postura do professor, pois ele pode ser questionado a qualquer momento, seja pelos alunos, pela 
coordenação pedagógica, pelos pais, inclusive pelos próprios colegas de área. Trabalhar a leitura de alguns autores clássicos, por vezes, tem colocado o docente diante do impasse entre o canônico x o não-canônico. O próprio fato de constatar a existência desse dilema pode parecer nostalgia do tempo em que se liam os clássicos na escola e apenas eles. Não se trata disso.

Os clássicos não podem ser o único horizonte de leitura de quem pretende promover a formação de leitores em sala de aula, mas eles não podem ser banidos do espaço escolar sem que os estudantes percam a oportunidade de entrar em contato com a memória literária e cultural que os antecedeu. A escola pode trabalhar a leitura de Machado de Assis, Fernando Pessoa e Clarice Lispector, para me deter em alguns nomes. Ou melhor, a escola pode trabalhar a leitura desses autores e incentivar a prática da escrita ao mesmo tempo, por isso o exercício de reescrita literária é tão produtivo.

Foram debatidas aqui duas reescritas de contos machadianos realizadas por estudantes do segundo ano do ensino médio de uma escola pública gaúcha, pois cada uma, a seu modo, comprova que os clássicos podem fazer sentido para jovens leitores. Nossos estudantes, na esteira de Antonio Candido, têm o direito de conhecer Machado de Assis na escola, assim como têm o direito fundamental de frequentar escolas que possibilitem o trabalho com esses e outros nomes da literatura. Machado de Assis, Graciliano Ramos, Clarice Lispector não podem levar a culpa por aulas voltadas para ensinar a assinalar a alternativa correta nas questões da prova do vestibular nem pela falta de investimento em uma educação pública de qualidade.

\section{Referências}

CALVINO, Ítalo. Por que ler os clássicos. São Paulo: Companhia das Letras, 2007.

CANDIDO, Antonio. Vários escritos. Rio de Janeiro: Ouro sobre azul, 2011.

CHARTIER, Roger. A aventura do livro: do leitor ao navegador. São Paulo: Editora UNESP/ Imprensa Oficial do Estado, 1999.

COSSON, Rildo. Círculos de leitura e letramento literário. São Paulo: Contexto, 2014.

DIAS, Ana Crélia. Literatura e educação literária: quando a literatura faz sentido(s). Revista Cerrados, Brasília, v. 25, n 42. Disponível em:

$<$ http://periodicos.unb.br/index.php/cerrados/article/view/210-228/15647>. Acesso em: 13 jul. 2017. 
HOUDART-MÉROT, Violaine. Da crítica de admiração à leitura "scriptível". In: ROUXEL, A.; LANGLADE, G.; REZENDE, N. L. (Orgs.). Leitura subjetiva e ensino de literatura. São Paulo: Alameda, 2013.

LEAHY-DIOS, Cyana. LEAHY-DIOS. Educação literária como metáfora social. Niterói: Editora da Universidade Federal Fluminense, 2000.

ROUXEL, A. A tensão entre utilizar e interpretar na recepção de obras literárias em sala de aula: reflexão sobre uma inversão de valores ao longo da escolaridade. In: ROUXEL, A.; LANGLADE, G.; REZENDE, N. L. (Orgs.). Leitura subjetiva e ensino de literatura. São Paulo: Alameda, 2013.

Recebido em: 10/02/2019 Aceito para publicação em: 15/03/2019 